Wojciech Życiński SDB

\title{
DOGMAT MARYJNY W KONTEKŚCIE DOGMATU TRYNITARNEGO
}

\author{
PERSPEKTYWA HISTORIOZBAWCZA
}

Prawdy wiary chrześcijańskiej zawarte $\mathrm{w}$ dogmacie trynitarnym są niewątpliwie największą tajemnicą tejże wiary. Niektórzy z teologów określają ją nawet mianem „Tajemnicy Tajemnic”. Jeden i jedyny Bóg objawia się wobec człowieka jako Trójca Bożych Osób, które łączy jedność boskiej natury. W przypadku Drugiej Osoby Boskiej natury są dwie, a osoba jedna. Jeśli chodzi natomiast o Ducha Świętego, to do niedawna teologowie raczej mało się Nim zajmowali. Równie trudny do przyjęcia wydaje się Boży plan odkupienia ludzkości. Inicjatywa należy do Ojca, który w tym celu posyła Syna, zrodzonego, a nie stworzonego, a Duch Święty, który od Ojca i Syna pochodzi, prowadzi do pełnej prawdy. W realizacji tego planu Bóg posługuje się też człowiekiem, nieznaną dotychczas z kart Biblii Marią z Nazaretu, która w tajemnicy wcielenia odegrać ma istotną rolę. Czy można mówić o wzajemnych relacjach zachodzących między Bogiem a człowiekiem? Czy można porównywać Stwórcę ze stworzeniem? Otóż można, ale z zachowaniem właściwych proporcji. Człowiekowi nie można nigdy

1 S. C. Napiórkowski, Trójca Święta i Maryja oraz teologowie Polscy, [w:] Trójca Święta a Maryja. Materiaty z sympozjum mariologicznego zorganizowanego przez Polskie Towarzystwo Mariologiczne. Częstochowa, 6-8 września 1999 roku, red. nauk. T. Siudy, K. Pek, Częstochowa 2000, s. 5. 
przypisywać cech boskich, jak też jego ludzkich zasług, które odgrywałyby istotną rolę $w$ dziele odkupienia. $Z$ drugiej strony kenoza Bożego Syna, czyli wcielenie i krzyż, to przejaw ogromnej miłości Boga do człowieka, okazanej przez Syna i w Duchu Świętym. Jest to zarazem kenoza Trójcy Świętej. Odpowiednio więc do roli, jaką Bóg przewidział dla Maryi w ekonomii zbawczej, została Ona w sposób szczególny włączona $\mathrm{w}$ tajemnicę trynitarną, a więc również $\mathrm{w}$ tajemnicę kenozy $^{2}$. Owo włączenie jest jednak wzajemne, ponieważ Boży Syn, stając się człowiekiem, sprawił, że nie tylko człowiek i jego dzieje stały się uczestnikiem Bożego życia, ale również Bóg w Jezusie Chrystusie stał się uczestnikiem historii i dziejów ludzkich. „Fiat” wypowiedziane przez Maryję w dniu zwiastowania zapoczątkowało nową i nierozerwalną relację między Bogiem a ludzkością, która była nie tylko zapowiedzią, ale też zapoczątkowaniem Drugiego Przymierza dokonanego w krwi Chrystusa ${ }^{3}$. Maryjne „fiat” jest jakimś echem „fiat” wypowiedzianego przez Stwórcę u zarania ludzkości. We wzajemności tego włączenia św. Jan Paweł II dostrzega miejsce spotkania Trójcy i historii ludzkiej, Stwórcy i stworzenia, Bożej wszechmocy i ludzkich ograniczeń, ucząc, że szczególna relacja Maryi z Trójcą Świętą przewyższa ludzkie odniesienie do Boga, ale samej Maryi nie wynosi ponad ludzi ${ }^{4}$. Także dziś stanowi Ona wielki znak macierzyńskiego i miłosiernego oblicza Boga w Chrystusie oraz wyraz miłości wobec Ojca, zażyłości z Synem i otwartości na działanie Ducha Świętego.

Ten ścisły związek Maryi z Trójcą Świętą zapoczątkowany został Bożym wybraniem, które było zarówno objawieniem Jego chwały, jak i majestatu łaski wobec człowieka (zob. Ef 1, 6-7). Maryja, uczy Jan Paweł II, pozostaje w ten sposób wobec Boga, a także wobec całej ludzkości, jakby niezmiennym i nienaruszonym znakiem tego Bożego wybrania, o jakim mówi list Pawłowy: „w Chrystusie wybrał nas przed założeniem świata [...] i przeznaczył dla siebie jako przybranych synów. Wybranie to jest potężniejsze od wszelkich doświadczeń zła i grzechu, od całej owej nieprzyjaźni, jaką naznaczone są ziemskie dzieje człowieka. Maryja pozostaje w tych dziejach znakiem

2 Zob. W. Życiński, Encyklika Redemptoris Mater, [w:] Zrozumieć, aby czcić. Encykliki Jana Pawła II, red. M. Cholewa i in., Kraków 2014, s. 93-96.

Zob. A. Maggi, Nostra Signora degli eretici. Maria e Nazaret, Assisi 1997, s. 65.

4 Zob. Jan Paweł II, Discorso durante l'Udienza Generale, 10.01.1996, „L'Osservatore Romano" 1996, 11 gennaio, s. 136, n. 7,4. 
niezawodnej nadziei" ${ }^{5}$, ponieważ to sam Bóg wybiera Ją na Matkę swego Syna i obdarza jedynym i niepowtarzalnym w dziejach ludzkości przywilejem. Bóg wybrał Ją w sposób wolny i bezinteresowny, a odkupił w sposób wznioślejszy od pozostałych ludzi, bo poprzez Niepokalane Poczęcie. Jan Paweł II uczy, że to

\begin{abstract}
za sprawą łaski Umiłowanego, ze względu na odkupieńcze zasługi Tego, który miał stać się Jej Synem poczętym z Ducha Świętego, Maryja została uwolniona od dziedzictwa grzechu pierworodnego. W ten sposób od pierwszej chwili poczęcia, czyli zaistnienia w wymiarze biologicznym i ziemskim, należy Ona do Chrystusa, ma udział w zbawczej łasce uświęcającej oraz w tej miłości, która swój początek znajduje w „Umiłowanym”, w Synu Ojca Przedwiecznego, który poprzez wcielenie stał się Jej rodzonym Synem. Dlatego za sprawą Ducha Świętego, w wymiarze łaski, Maryja otrzymuje życie od Tego, któremu w porządku ziemskiego rodzenia sama dała życie jako Matka ${ }^{6}$.
\end{abstract}

Wzajemne relacje między dogmatem maryjnym a trynitarnym ukazuje nam Łukaszowy opis powołania i przeznaczenia Maryi do Bożego macierzyństwa. Syn, którego z Ducha Świętego poczęła i porodziła, był tym samym, który nazwany miał być Synem Najwyższego i Synem Bożym. Odtąd (czyli od zwiastowania) całe Jej życie, aż po Golgotę, zjednoczone jest z Tym, który był Bożym i Jej Synem. Tajemnica wcielenia uświadomiła ludzkości prawdę o „wielkim przełomie" dla człowieka. Obejmuje on całe ludzkie dzieje, poczynając od stworzenia, poprzez upadek aż po powstanie, czyli od grzechu po łaskę. W przełomie tym, obok Chrystusa, istotna rola przypada również Jego Matce ${ }^{7}$. To Ona bowiem pojawiła się przed Chrystusem na horyzoncie dziejów zbawienia, poprzedzając Jego przyjście, przygotowując się nań i w wierze oraz łasce odpowiednio usposabiając. Obecność Jej pośród Izraela, jak pisze Jan Paweł II, dyskretna i chyba niezauważona, pozostawała równocześnie przejrzysta i jawna wobec Przedwiecznego, który z tą ukrytą Córką Syjonu związał swój zbawczy plan obejmujący całe dzieje ludzkości ${ }^{8}$.

5 Jan Paweł II, Encyklika Redemptoris Mater [dalej: RM], [w:] Encykliki Ojca Świętego Jana Pawta II, Kraków 2003, 11.

6 RM 10.

7 RM 52.

8 RM 3. 
Trzeci aspekt wzajemnych relacji między Maryją a Trójcą Świętą wyraża działanie Ducha Świętego w Najświętszej Dziewicy, zwłaszcza w kontekście dziewiczego poczęcia Jezusa. Duch Święty sprawia bowiem, że powołanie i przeznaczenie Maryi do Bożego macierzyństwa zostaje zrealizowane. Dzięki Jego działaniu w Maryi możliwe staje się zawarcie przez Boga Ojca Nowego Przymierza z całą ludzkością w krwi Chrystusa. Relacja Maryi z Duchem Świętym pozwala też lepiej dostrzec i zrozumieć obecność i działanie Trójcy Świętej w toczącej się historii zbawczej. Wskazuje ona bowiem nie tylko na osobę Bożej Rodzicielki, ale też odnosi się do samego działania Ducha Świętego jako owocu miłości Ojca i Syna, a z Maryi czyni uczestniczkę tajemnicy trynitarnej. Teologia prawosławna jeszcze bardziej rozwija ten aspekt, mówiąc o Maryi jako „ikonie Ducha Świętego i szczególnym sanktuarium, w którym Bóg spotyka się z człowiekiem". Jan Paweł II stwierdził natomiast, że ze względu na szczególne i niepowtarzalne zjednoczenie Maryi z trzema Osobami Bożymi jest Ona pierwszą i autentycznie wierzącą chrześcijanką ${ }^{10}$. W pełni bowiem realizuje powołanie, jakie przewidział dla Niej Stwórca, odpowiada na nie w sposób wolny, świadomy i odpowiedzialny, a wobec Boga i bliźnich okazuje postawę pokornej Służebnicy. Z tego też względu Kościół od początku patrzył na Maryję poprzez Jezusa tak samo, jak poprzez Maryję patrzył na Jezusa, a poprzez Matkę i Syna na Ojca i Ducha Świętego. Tak dla Kościoła pierwotnego, jak i dla Kościoła wszystkich czasów Maryja była i zawsze pozostaje nade wszystko tą błogosławioną, która uwierzyła, stając się pierwszą chrześcijanką. Wiara pielgrzymującego Kościoła staje się więc w powyższym kontekście przedłużeniem wiary Maryi.

\section{„Bądź pozdrowiona, pełna łaski, Pan z Tobą". Bóg Ojciec a Maryja}

Doktryna z zakresu soteriologii traktująca o odkupieniu człowieka należy do fundamentów wiary chrześcijańskiej. Zawiera się w niej

9 Zob. A. Fusi, Ha creduto meglio degli altri. Maria modello della Chiesa nell'insegnamento di Giovanni Paolo II, Milano 1999, s. 31.

10 Giovanni Paolo II, Discorso dell’Angelus, 29 maggio 1983, „Insegnamenti” VI, 1, 1390. 
prawda o samoobjawieniu się Boga wobec reprezentującego ludzkość narodu wybranego w Starym Testamencie, a bardziej jeszcze w osobie Słowa Wcielonego i tajemnicy mesjańskiej. Bóg dokonywał samoobjawienia na różne sposoby stosownie do czasów ${ }^{11}$. Formy tegoż objawienia ukazywały człowiekowi nieskończoną miłość Boga. Powszechność zbawczego planu Stwórcy wobec człowieka, objawiona na kartach Biblii, ukazuje potrzebującej zbawienia ludzkości możliwość uczestnictwa w życiu Ojca, Syna i Ducha Świętego. W ten sposób historia Boga Trójosobowego, historia zbawienia staje się też historią człowieka. W realizację zbawczego planu Boga włączona była również Maryja z Nazaretu, Matka, Służebnica i uczennica Bożego Syna, pierwsza chrześcijanka.

\section{Maryja znakiem darmowej i zbawczej miłości Boga} Trójosobowego. Wybrana i umiłowana córka Ojca Przedwiecznego

Pierwszy artykuł credo nicejsko-konstantynopolitańskiego zawiera wyznanie wiary chrześcijańskiej „w Boga Ojca wszechmogącego". W tym samym credo, jak i w celebracji liturgicznej i codziennych modlitwach, chrześcijanie wyznają też wiarę „w jednego Pana Jezusa Chrystusa, Syna Bożego jednorodzonego” oraz „w Ducha Świętego, Pana i Ożywiciela, który od Ojca pochodzi"12. W Starym Testamencie termin „Ojciec” wyrażał szczególną relację Boga z Izraelem. W Nowym natomiast pozyskał znaczenie bardziej brzemienne: Bóg rzeczywiście jest Ojcem Jezusa Chrystusa, a w Nim i przez Niego także naszym Ojcem (Gal 4, 4-5). Narodzenie Bożego Syna z Maryi na polach betlejemskich pasterzy staje się więc niewyobrażalnym spotkaniem Boga z człowiekiem i jedynym wprost sposobem objawienia łaski, którą Bóg obdarza człowieka. Droga wcielenia prowadzi do samej istoty chrześcijaństwa, ponieważ Ojciec jest źródłem zarówno boskości i zbawienia, jak też kresem drogi prowadzącej do Ojca, a wskazanej przez Jego Syna ${ }^{13}$.

1 S. M. Perrella, La Madre di Gesù nella coscienza ecclesiale contemporanea. Saggi di teologia, Città del Vaticano 2005, s. 434.

12 Dokumenty Soborów Powszechnych, red. A. Baron, H. Pietras, t. 1, 325-787, Kraków 2001, s. 25 (Źródła Myśli Teologicznej, 24).

$13 \quad$ S. M. Perrella, La Madre..., dz. cyt., s. 96. 
Bóg Ojciec jest nie tylko centrum tajemnicy trynitarnej, ale również Tym, który posyła swoje Słowo na świat i w ludzką historię, aby odnowić przymierze $\mathrm{z}$ narodem wybranym, które nigdy nie zostało odwołane, ale miało się wypełnić w krzyżowej śmierci Jego Syna, w którym wyraża się Ojcowska miłość, dzięki której wszyscy ludzie mogą stać się Jego synami w Synu (Gal 4, 4-6). Abyśmy mogli otrzymać przybrane synostwo, jak pisze św. Paweł, Bóg posyła w pełni czasów swego Syna zrodzonego z niewiasty i zrodzonego pod Prawem. Niewiastę tę Katechizm Kościoła katolickiego określa mianem „Młodej Żydówki", a którą jest Maria z Nazaretu. Odwieczny Bóg wybiera, powołuje i przeznacza na Matkę swojego Syna nastolatkę z Nazaretu, włączając Ją tym samym w realizację swego zbawczego planu. Rozważając to wielkie misterium wiary chrześcijańskiej, Kościól, poczynając od macierzyńskiej misji Maryi wobec Bożego Syna, postrzega Ją jako najbardziej umiłowaną córkę Ojca i przybytek Ducha Świętego $^{14}$. Teologia natomiast widzi w Niej macierzyńską ikonę ojcostwa Boga, czemu wyraz daje między innymi Angelo Amato, aktualny prefekt Kongregacji do spraw Świętych: „w Bożym macierzyństwie Maryi trzeba dostrzec ludzki i stworzony obraz ojcostwa Boga"15. Bruno Forte natomiast w powyższym kontekście napisze na kartach Maria, la donna icona del Mistero:

\footnotetext{
Poprzez macierzyństwo Maryi Bóg Ojciec objawia się jako ten, który zainicjował bezinteresowną miłość i dlatego jest początkiem wszelkiej miłości tego typu. Matka Boża zadziwiona źródłem tej tajemnicy, kieruje nas ku świętej Matce świata - ku Bogu Trójosobowemu, trzykroć świętemu, w którym wszystko co istnieje ma swój początek ${ }^{16}$.
}

Imię Maryi pochodzącej z rodu Abrahama, należącej do narodu wybranego, rozważane bez żadnych upiększeń, przymiotników i dodatków, z woli Wszechmogącego Ojca tegoż narodu wybrane zostało jako imię Jego umiłowanej córki oraz Matki Pana życia, historii

\footnotetext{
14 Por. Katechizm Kościoła katolickiego [dalej: KKK], Poznań 1994, 237.

15 A. Amato, La SS Trinità e Maria. Sintesi teologica, [w:] I. de la Potterie, Come collaborare al progetto di Dio con Maria. Principi e proposte", Roma 1985, s. 34 (Mater Ecclesiae, Serie Pastorale, 11).

16 B. Forte, Maria, la donna icona del Mistero. Saggio di mariologia simbolico-narrati$v a$, Milano 1989, s. 204-205 [tłum. własne - W. Ż.].
} 
i wiary. To On bowiem wejrzał na uniżenie Służebnicy swojej, jako Wszechmocny uczynił Jej rzeczy wielkie, obdarował łaską. To w Niej i przez Nią stworzenie może powrócić do swego Stworzyciela. Jest Ona zatem znakiem widzialnym nowej ludzkości i świata, znakiem skutecznym. Ojcowska miłość Boga wobec człowieka, narodu wybranego i ludu Bożego, jakim jest Kościól, znajduje bowiem przedłużenie w macierzyńskiej miłości Maryi wobec Jezusa i Jego uczniów ${ }^{17}$.

\section{Ojciec miłosierdzia dla Służebnicy Pańskiej i swego Ludu rzeczy wielkie czyniący}

Bóg, realizując swój zbawczy zamysł wobec człowieka, stopniowo dawał mu się też poznać. Tradycyjne sformułowanie „przez Maryję do Jezusa" Jan Paweł II w encyklice Redemptoris Mater uzupełnia innym - „przez Jezusa do Maryi”. Rozważając relacje zachodzące między Maryją a poszczególnymi osobami Trójcy Świętej, uzasadnione wydaje się też stwierdzenie: przez Maryję do Ojca. Poprzez osobę Matki Chrystusa Bóg mówi też do nas, przedstawia się nam i przedstawia nam Maryję. Informuje nas, że Syn Najwyższego narodzi się z Dziewicy, że poczęty zostanie z Ducha Świętego bez udziału mężczyzny, a On sam, Stwórca, kierowany wolną i bezinteresowną miłością do człowieka, zdecydował nie oszczędzić nawet własnego Syna, ale Go za nas wszystkich wydać ${ }^{18}$. Syn Maryi jest Synem Bożym (verus Deus). Syn Boży jest Synem Maryi (verus homo). Jego cielesne zrodzenie dokonało się nie dzięki ludzkim możliwościom (człowiek nie może zrodzić Boga), ale stanowi przejaw Bożej wszechmocy. Od momentu wcielenia, jak pisze Bruno Forte, każdy, kto szukałby Boga, pomijając Syna Maryi, nigdy nie będzie miał pełnego dostępu do tajemnicy bóstwa ${ }^{19}$. Maryja jako Boża Rodzicielka, będąca ludzkim łonem Boga wcielonego, potwierdza solidarność Stworzyciela ze stworzeniem. Boży Syn zrodzony z Maryi objawia się w ludzkim ciele, jest widzialny i dotykalny, bez zasłony można z Nim rozmawiać twarzą

17 A. Serra, Il Padre celeste e la Madre terrena. Convergenze nella storia della salvezza, [w:] Maria e il Dio dei nostri padri, Padre del Signore nostro Gesù Cristo. (XII Simposio Interna zionale Mario logico. Roma, ottobre 1999), ed. E. Toniolo, Roma 2001, s. 229.

18 Por. B. Forte, Maria..., dz. cyt., s. 200.

19 B. Forte, Maria..., dz. cyt., s. 201. 
w twarz, a zarazem objawia On Tego, który Go posłał jako Syna Maryi. Dlatego zdaniem Maxa Thuriana nazywać Maryję Matką Bożą to nic innego jak uznawać, że Bóg wcielił się tak całkowicie i realnie w nasze ciało, iż miał prawdziwie ludzką Matkę i że był Synem ludzkim w ludzkiej rodzinie ${ }^{20}$. Zważywszy, że poczęciu Syna towarzyszyła moc Najwyższego i działanie Ducha Świętego, mamy prawo twierdzić, że Bóg chrześcijan nie jest samotnikiem, ale relacją między Ojcem a Synem i między nimi a Duchem Świętym.

Jak teologia chrześcijańska postrzega zatem osobę Maryi wobec Boga Ojca? Święty Tomasz nie obawiał się nazwać Jej creatura pura wobec Stworzyciela. To czyste stworzenie, jakim była Boża Rodzicielka, ma jednak świadomość swojej stworzoności i wielkich dzieł Stwórcy, które dla Niej i przez Nią uczynił dla narodu wybranego i ludu Nowego Przymierza. Daje temu wyraz w hymnie Magnifi$c t^{21}$, w którym stary Izrael łączy się z nowym, a radość Abrahama łączy się z antycypowaną radością Kościoła. Dziękczynna i wielbiąca Boga modlitwa Maryi staje się modlitwą Kościoła. Wiara Rodzicielki, że Stwórca może uczynić Ją Matką Syna Najwyższego bez udziału mężczyzny, bo u Boga nie ma nic niemożliwego, stała się też wiarą Kościoła, pełną i ufną, ale też poszukującą zrozumienia i ludzkiego wsparcia. Kościół znajduje je w wierze Maryi ${ }^{22}$. Matka Pana wielbi Boga, który na Nią wejrzał i „uczynił Jej rzeczy wielkie” (Łk 1, 4649). Ewangelista przekazuje nam swoisty dekalog owych wielkich dzieł dokonanych przez Boga, wyrażanych w formie czasownikowej: wejrzał, uczynił, okazał, rozproszył, złożył, wywyższył, nasycił, odprawił, ujął się, przyobiecał.

Wielkie rzeczy czynione przez Boga (magnalia Dei) oznaczają w Starym Testamencie nadzwyczajne interwencje w dzieje ludu wybranego. Najczęściej określenie to odnoszone było do wydarzeń towarzyszących wyjściu z niewoli egipskiej. Wielkie rzeczy uczynił Bóg dla Mojżesza, a za jego pośrednictwem - dla narodu wybranego. Wielkie rzeczy uczynił też dla Maryi, a za Jej pośrednictwem dla

\footnotetext{
20 Por. M. Thurian, Maryja Matka Pana, figura Kościota, przeł. E. Ogiński, Warszawa 1990, s. 97 (Theotokos. Seria Mariologiczna, 2).

${ }_{21}$ Zob. W. Życiński, Mariologia, [w:] Dogmatyka w perspektywie Bożego miłosierdzia, red. K. Góźdź, K. Guzowski, Lublin 2010, s. 139-140, 144.

22 Por. J. Kudasiewicz, Matka Odkupiciela, Kielce 1996, s. 36-37 (Maryja w Dziejach Zbawienia, 1).
} 
Kościoła. Zatem już w pierwszym rozdziale Ewangelii według św. Łukasza mariologia ściśle łączy się z chrystologią i eklezjologią. „Wielkie rzeczy Boga" to innymi słowy łaska, czyli miłosierdzie, jakie okazuje On człowiekowi, by w Synu dokonać odkupienia swojego ludu. Bóg Maryi jest tym samym Bogiem, który objawił się Mojżeszowi jako „miłosierny i litościwy, cierpliwy, bogaty w łaskę i wierność, zachowujący swą łaskę w tysiączne pokolenia, przebaczający niegodziwość, niewierność, grzech, lecz nie pozostawiający go bez ukarania, ale zsyłający kary za niegodziwość ojców na synów i wnuków aż do trzeciego i czwartego pokolenia" (Wj 34, 6-7). Bóg Mojżesza i Maryi realizuje za pośrednictwem Matki swojego Syna obietnice złożone wcześniej Abrahamowi, ponieważ Jego miłosierdzie to delikatna i pełna miłości troska oraz ciągła gotowość do przebaczania. Bóg ten nachyla się nad swym ludem, a szczególnie nad tymi, którzy się Go boją. Jego egzystencja jest proegzystencją ${ }^{23}$.

Jakie zatem wielkie rzeczy uczynił i nadal czyni dla Maryi i przez Maryję, czyli dla człowieka i przez człowieka, a więc dla Kościoła i przez Kościół Ten, który jest Wszechmocnym, Miłosiernym i Proegzystującym Bogiem? Max Thurian przyjmuje w pełni jako własne słowa Karla Bartha, pisząc: „Jaka niewypowiedziana wielkość w tym zestawieniu: całkiem zwykły, niepozorny fakt, że u Boga wystarczy jedno tylko wejrzenie, aby wylać pełnię łaski, a z drugiej strony potęga i ogromne znaczenie tego wydarzenia"24. Renzo Bertalot, teo$\log$ z Kościoła Waldensów, owo wejrzenie Boga na Maryję postrzega (za Marcinem Lutrem) w kategoriach wolnego i niczym nieuwarunkowanego działania Boga, które stawia na równi z nowym stworzeniem ex nihilo lub ex amore ${ }^{25}$. Wejrzenie Boga na uniżenie Jego Służebnicy było równocześnie wybraniem i obdarowaniem łaską macierzyństwa Syna Najwyższego. Od tego uzależniona była wieczna przyszłość człowieka, stosownie do podjętego odwiecznie Bożego zamysłu.

Paradoksalnie możemy więc powiedzieć, że zbawienie zawdzięczamy człowiekowi (kobiecie), w czym utwierdza nas jeszcze świadectwo ojców Kościoła wyrażane przekonaniem, że Bóg stworzył nas

23 Por. W. Życiński, Mariologia, dz. cyt., s. 139-140.

24 M. Thurian, Maryja Matka Pana..., dz. cyt., s. 106 [tłum. własne - W. Ż.].

25 Por. R. Bertalot, Ecco la Serva del Signore. Una voce protestante, Roma 2002, s. 48. 
bez nas, ale nie zbawi nas bez naszego udziału. Bóg działa bowiem zgodnie z naturą stworzeń, zaś w naturze człowieka leży wolność; korzystając z niej, nawet Bogu może on powiedzieć „nie będę służył”. Matka Pana uczy nas, używając języka św. Pawła, jak być współpracownikiem Boga, a więc jak odpowiadać pozytywnie na Boże i zbawcze inicjatywy podejmowane wobec nas, które wypływają z bezmiaru Jego miłosierdzia i ogromnej miłości do człowieka. W powyższym kontekście zupełnie inaczej odczytujemy słowa Maryi „błogosławić mnie będą odtąd wszystkie pokolenia" (Łk 1, 48). Słowa te oznaczają po prostu, że odtąd (od zwiastowania w Nazarecie) wszystkie pokolenia wielbić będą Boga za Jego miłosierdzie, jakie poprzez Maryję okazał swojemu ludowi. My jesteśmy tym ludem, który, nazywając Maryję błogosławioną, oddaje cześć Bogu w Maryi, z Maryją i tak jak Maryja. Bóg bowiem, jak uczył Marcin Luter, kocha nas nie dlatego, że jesteśmy dobrzy, ale czyni nas dobrymi dlatego, że nas kocha.

\section{"Oto poczniesz i porodzisz Syna, któremu nadasz imię Jezus”. Syn Boży a Maryja}

Jezus Chrystus, prawdziwy Bóg i prawdziwy człowiek, ma również podwójne pochodzenie: boskie - jako Słowo Ojca i ludzkie jako Słowo Wcielone. O wcieleniu Słowa, które jest Synem Bożym, czytamy w Ewangeliach według św. Mateusza, Łukasza i Jana oraz w Liście do Galatów. Paweł i Jan piszą o pochodzeniu boskim (z Ojca) i ludzkim (z Matki), zaś Mateusz i Łukasz tylko o narodzeniu ziemskim, które poprzez genealogię włączone jest nie tylko w historię narodu wybranego (Mt 1,1-16), ale również w historię ludzkości (Łk 3, 2338). W genealogii imię Maryi pojawia się tylko w Ewangelii według św. Mateusza. Jednak wszystkie teksty jednoznacznie poświadczają, że to z Niej „narodził się Jezus” (Gal 4, 4; Mt 1, 16) a Ona jest „Matką Jezusa" (J 2,1).

\section{Misterium Syna wyjaśnieniem misterium Matki, która pozostała Dziewicą}

W Biblii imię Maryi pojawia się po raz pierwszy w Ewangelii według św. Mateusza. Wymienione jest na końcu trzeciej części drzewa genealogicznego, które początkami sięga Abrahama, a kończy się na 
Jezusie, Synu Maryi. Mateusz, wbrew zwyczajom, włączył do genealogii Maryję i cztery niewiasty ze Starego Testamentu: Tamar - żonę Judy, Rahab - żonę Salmona, Rut - żonę Booza i Batszebę - żonę Dawida. Nie robi tego natomiast Łukasz, którego Ewangelia otwarta jest bardzo na aspekt niewieści. Zdaniem biblistów Mateusz wymienia starotestamentalne niewiasty w genealogii Jezusa, ponieważ wszystkie je łączy w pewnej mierze nieregularność związku małżeńskiego, a ponadto wszystkie zostały matkami w sposób, który można nazwać wręcz nadzwyczajnym. Tak było też w przypadku małżeństwa Maryi i Józefa. Mimo to niewiasty owe odegrały bardzo ważną rolę w historii Izraela i historii dynastii. René Laurentin twierdzi nawet, że nieregularność ich związku małżeńskiego i macierzyństwa stanowią niejako przygotowanie do wykraczającego poza wszelkie reguły dziewiczego macierzyństwa Maryi wobec Jezusa ${ }^{26}$. On sam w powyższym kontekście przedstawiany jest przez ewangelistę jako Mesjasz, który przyszedł po to, by zbawić wszystkich. Nie Józef jednak jest Jego ojcem. Małżeństwo w Izraelu stawało się wiążące mocą prawa z chwilą złożenia obietnicy małżeńskiej. Na korzystanie z praw małżeńskich zezwalało jednak dopiero wspólne zamieszkanie. W przypadku Maryi i Józefa ten drugi wymóg nie został jeszcze spełniony. Mateusz zna starotestamentalne zapowiedzi dotyczące pochodzenia i miejsca narodzin Mesjasza. Zna też prawdę o dziewiczym macierzyństwie Jego Matki. Dlatego też robi jeden wyjątek w sposobie prezentacji genealogicznej przodków Jezusa, poczynając od Abrahama. Kiedy bowiem genealogia dochodzi do Chrystusa, Mateusz zmienia dotychczasowy sposób opisu pochodzenia i w miejsce "Józefa, ojca Jezusa” wstawia „Józefa, męża Maryi, z której narodził się Jezus, zwany Chrystusem" (Mt 1, 16), ponieważ wcześniej (nim zamieszkali razem) „znalazła się brzemienną za sprawą Ducha Świętego” (Mt 1, 18) i dlatego „z Ducha Świętego jest To, co się w Niej poczęło” (Mt 1, 20).

René Laurentin jest przekonany, że Mateusz wymienia owe niewiasty ze Starego Testamentu już na początku swojej Ewangelii, by w ich perspektywie ukazać zupełnie odmienną i wyjątkową funkcję macierzyńską Maryi wobec Mesjasza. Tylko Ona sama bowiem jest tą, od której Syn Boży otrzymał ludzką naturę. Z tego też względu jest Ona wymieniona jako przedostatnia w łańcuchu genealogicznym 
i umieszczona między dwoma zrodzonymi, a nierodzącymi: Józefem, prawnym opiekunem i Jezusem - ostatnim ogniwem genealogii. Zamykająca ziemskie pochodzenie Mesjasza triada: Józef - Maryja - Jezus nazywana jest przez teologów „ziemską Trójcą, która daje początek nowej ludzkości”27.

Prawdę o dziewiczym macierzyństwie Maryi potwierdza również Ewangelia Łukaszowa, według której samo poczęcie dokonało się dzięki działaniu Ducha Świętego. Niewątpliwie doktryna o semper virgo stanowi przejaw tajemnicy wiary. Dla chrześcijanina XXI wieku wobec niemożliwości weryfikacji empirycznej faktu dziewictwa Maryi istotną rolę odgrywa sensus fidei oraz wiara w obecność i działanie Ducha Świętego. Dziewictwo Maryi postrzegane jest przez Kościół jako zewnętrzny znak Jej wewnętrznej dyspozycji całkowitego poświęcenia się Bogu i akceptacji Jego powszechnego planu zbawienia. Oznacza ono, jak pisze $\mathrm{M}$. Thurian, teolog ewangelicki, a następnie rzymskokatolicki, że Matka Chrystusa jest istotą wyjątkową, wybraną przez Boga w sposób uprzywilejowany i powołaną do wyjątkowej funkcji. Dzięki temu znajduje się w szczególnej i wyjątkowo bliskiej relacji z Bogiem, ukierunkowanej na realizację zbawczego planu ${ }^{28}$. Bóg Ojciec wybiera Maryję na Matkę-Dziewicę swojego Syna ${ }^{29}$, którego wcielenie staje się możliwe dzięki działaniu Ducha Świętego.

Tajemnica dziewiczego poczęcia i wcielenia Bożego Syna objawia nam prawdę o tym, że inicjatywa zbawcza należy do Boga, że jest ona wyrazem Jego bezgranicznej miłości wobec całej ludzkości. By zrealizować swój zbawczy zamysł, Bóg wybiera odwiecznie kilkunastoletnią mieszkankę Nazaret na Matkę Zbawiciela, obdarzając Ją nieskończoną godnością. Maryja, otrzymując zapewnienie, że Duch Święty zstąpi na Nią i osłoni Ją moc Najwyższego, podejmuje decyzję o współpracy z Nieskończonym, która ukierunkowana była na wieczne zbawienie każdego człowieka ${ }^{30}$. Inicjatywa wychodzi od Boga, nie od Maryi. Człowiek nie ma mocy zbawczej ani wobec siebie, ani wobec innych. Może być jednak, zgodnie z nauczaniem św. Pawła, współpracownikiem Boga. Jest nim wtedy, gdy tak

\footnotetext{
27 S. Manelli, Mariologia biblica, Frigento 2005, s. 65 [tłum. własne - W. Ż.].

28 Zob. M. Thurian, Maryja Matka Pana..., dz. cyt., s. 43-44.

29 Zob. A. M. Calero, La Vergine Maria nel mistero di Cristo e della Chiesa. Saggio di mariologia, Torino 1995, s. 137.

30 Zob. B. Forte, Maria..., dz. cyt., s. 172.
} 
jak Maryja odpowiada przyjęciem Bożych propozycji. Matka Pana sama z siebie nie mogłaby niczego dokonać, gdyby nie odwieczne wybranie i powołanie Jej przez Boga. Matką Syna Najwyższego została nie dlatego, że była dziewicą, ale dlatego, że Najwyższy jako dziewicę Ją wybrał, a za pośrednictwem Ducha moc Najwyższego sprawiła w Niej poczęcie ${ }^{31}$.

W ekonomii zbawczej realizacja obietnic jest wyłącznym dziełem Boga. W opisach starotestamentalnych zwiastowań znakiem działania Boga w cudzie narodzin (macierzyństwa Sary, Rdz 15, 16-17; Anny, 1 Sm 1, 11; 2, 1-10; Racheli, Rdz 49, 25-26; Debory, Sdz 4, 17-22) były bezpłodność, podeszły wiek, ubóstwo. W zwiastowaniu Maryi zapowiadającym narodziny Mesjasza znakiem Bożego działania w „pełni czasów" jest dziewictwo. W wymiarze teologicznym narodzony z Maryi Jezus postrzegany jest przez apostoła Pawła jako „pierworodny między wielu braćmi” (Rz 8, 29), czyli jako Ten, który jest pierworodnym nowego stworzenia, dającym początek nowemu ludowi Bożemu, a w „pełni czasów” zapoczątkowującym erę mesjańską. Prawdziwy Bóg i prawdziwy Człowiek, zanim został pierworodnym Synem Maryi, już był pierworodnym wszelkiego stworzenia (Kol 1, 15.18) jako jedyny Syn Boga Ojca (J 1, 14.18). Maryja od tego momentu a staje się natomiast Matką, która nadal pozostaje Dziewicą.

\section{Matka Pana z Panem współcierpiąca}

Ewangelie nie wspominają o tym, aby Bóg wtajemniczył Maryję w szczegóły dotyczące realizacji Jej dziewiczego macierzyństwa, z wyjątkiem sposobu poczęcia. Według świadectwa anioła Matką została Maryja dziś („dziś w mieście Dawida narodził się wam Zbawiciel którym jest Mesjasz Pan”, Łk 2,11). Boże „dziś” staje się więc „dziś” ludzkim, „dziś” tych, którym zostało to objawione i którzy uwierzyli. „Dziś” wcielenia poprzez „dziś” wiary staje się „dziś” odkupienia. Dla Maryi rozpoczęło się nowe „dziś”, będące ustawicznym zaskakiwaniem $^{32}$. Wiele wydarzeń i ludzkich reakcji powodowało nie tylko ból, ale mogło też rodzić wątpliwości. Dla Matki Jezusa każde wydarzenie

$31 \quad$ B. Forte, Maria..., dz. cyt., s. 175.

32 Zob. B. Prete, Nuovissimi studi sullopera di Luca. Contenuti e prospettive, Torino 2002, s. 45-51. 
związane z Jej Synem staje się, zwłaszcza w Ewangelii Łukaszowej, podstawą do medytacji tych dzieł i słów Boga, które kierowane były do Niej. Stąd też w samej tylko Ewangelii dzieciństwa mamy dwukrotne powtórzenie stwierdzenia, że „Maryja zachowywała wszystkie te sprawy i rozważała je w swoim sercu" (Łk 2, 19; 2, 51). O wierności Maryi i Józefa wobec wymogów starotestamentalnego Prawa, mimo że zapoczątkowane zostało już prawo Nowego Przymierza, świadczy fakt poddania Jezusa rytuałowi obrzezania i ofiarowania Go w świątyni. Obrzezanie, którego dokonywano ósmego dnia po narodzinach, było znakiem Przymierza Boga z narodem wybranym oraz oficjalnym włączeniem nowo narodzonego do jego społeczności. Wtedy też nadawano dziecku imię. Ewangelista w zapowiedzi narodzin Jezusa podaje ogólnie, że czynności tej dokonać miała Maryja (Łk 1, 31), co nie było powszechnym zwyczajem, ponieważ obowiązek ten zwykle spoczywał na ojcu ${ }^{33}$.

Jeśli Łukasz zamierzał tym faktem wywyższyć Matkę Pana, to w opisie ofiarowania już tego nie robi, ponieważ włącza do tekstu nieznanej dotychczas i tajemniczej postaci sprawiedliwego i pobożnego Symeona. Tenże starzec (wcześniej sprawiedliwym i prawym nazwany też został Józef) wypowiada słowa: „Bo moje oczy ujrzały Twoje zbawienie, które przygotowałeś wobec wszystkich narodów: światło na oświecenie pogan i chwałę ludu Twego, Izraela" (Łk 2, 3032). Następnie kieruje do Maryi słowa zaprzeczające wcześniejszym. Zamiast zbawienia, światła i chwały pada zapowiedź upadku, sprzeciwu i miecza, który w Biblii był symbolem nie tylko wojny, ale też Słowa Bożego (Iz 49, 2). W Nowym Testamencie słowo Chrystusa porównywane jest do miecza (Ap 1, 16). W tradycyjnej interpretacji tego proroctwa widziano zapowiedź tego, że odrzucenie Syna przez naród spowoduje też ból i cierpienie Jego Matki. Współcześnie coraz częściej odczytuje się je w innym wymiarze aniżeli tradycyjny. Ból i cierpienie Maryi interpretowano na ogół w sensie zbawczym. Kierując się powyższą interpretacją, wyrosła na gruncie amerykańskim organizacja Vox Populi Mariae Mediatrici stawia sobie za cel doprowadzenie do ogłoszenia piątego dogmatu maryjnego o Maryi jako Współodkupicielce, Pośredniczce i Orędowniczce. Doktryna ta,

33 Zob. M. Masini, Maria di Nazaret: storia, mito, simbolo, interpretazioni, Padova 2006, s. 99 (I Volti di Maria di Nazaret, 2). 
w przekonaniu członków i zwolenników ruchu, znajduje swe uzasadnienie biblijne i obecna była zawsze również w Tradycji Kościoła i nauczaniu Magisterium ${ }^{34}$.

Maryja tymczasem była nie tylko Matką Chrystusa, ale też wzorem wiernego ucznia i pierwszą chrześcijanką. Wierność ucznia Chrystusa weryfikowana jest przede wszystkim uwarunkowaniami życia, w jakich realizowane są zobowiązania wynikające $\mathrm{z}$ wiary. Zawierzając słowu Boga o mającym się narodzić z Niej Mesjaszu, Maryja mogła oczekiwać innych aniżeli betlejemskie uwarunkowań Jego przyjścia na świat, innej reakcji ludu Izraela na spełnione zapowiedzi dotyczące przyjścia Mesjasza, innej wreszcie aniżeli na Golgocie i krzyżu realizacji dzieła zbawczego. Syn Najwyższego i Jej Syn od początku spotyka się ze sprzeciwem, zgorszeniem, odrzuceniem, a umiera na krzyżu. Matka jest tego wszystkiego świadkiem. Stąd też Jej wątpliwości: czy Bóg, któremu zawierzyła, nie dotrzymał obietnicy? Czy może Ona popełniła błąd, zawierzając Jego słowu? Czy też błąd popełnili i brak wiary okazali ci, którzy odrzucili Chrystusa? Słowo Boga o Chrystusie i słowo Chrystusa o Bogu i człowieku zmusza do zajęcia stanowiska. $Z$ tymi problemami musiała zmagać się Maryja. Jej wiara musiała doświadczać rozterek i wątpliwości. Dlatego też, jak często podkreślają ewangeliści, „zachowywała i rozważała słowa Jezusa i Jego czyny w swoim sercu". Robiła to, aby zająć właściwą postawę wobec Boga i wobec Syna, który mimo iż jest Synem Najwyższego, „został przeznaczony na upadek i na powstanie wielu w Izraelu, i na znak, któremu sprzeciwiać się będą" (Łk 2, 34).

Na zachowywanie i rozważanie przez Maryję słów Jezusa według św. Łukasza miał również wpływ opis zagubienia dwunastoletniego Syna w świątyni (Łk 2, 48). Według tradycji rabinackiej każdy chłopiec izraelski po ukończeniu trzynastego roku życia zobowiązany był do odbycia pierwszej pielgrzymki do Jerozolimy. Od tego czasu musiał też zachowywać wszystkie przepisy Prawa. Józef, jako prawy ojciec, zadbał o to, by Jezus odbył taką pielgrzymkę już w wieku

34 Zob. Mary Coredemptrix, Mediatrix, Advocate. Theological foundations, t. I, Towards a papal definition?, ed. M. Miravalle, Santa Barbara CA 1995; Mary Coredemptrix, Mediatrix, Advocate. Theological Foundations, t. II, Papal, pneumatological, ecumenical, ed. M. Miravalle, Santa Barbara CA 1996; Mary Coredemptrix. Doctrinal Issues Today, ed. M. Miravalle, Goleta CA 2002; M. Miravalle, With Jesus. The story of Mary co-redemptrix, Goleta CA 2003. 
lat dwunastu ${ }^{35}$. Po zakończeniu nabożeństwa Jezus pozostaje nadal w świątyni, gdzie dyskutuje z uczonymi Izraela. Maryja i Józef szukają Go „wśród krewnych i znajomych” (Łk 2, 44). Dopiero po trzech dniach odnajdują Jezusa $\mathrm{w}$ świątyni. Wtedy też Maryja wypowiada do Syna pierwsze słowa, jakie odnotowała Biblia: „Synu, czemuś nam to uczynił? Oto ojciec Twój i ja z bólem serca szukaliśmy Ciebie" (Łk 2, 48). Według tej samej Ewangelii są to zarazem słowa ostatnie, jakie skierowała do Jezusa. Odpowiedź Syna „Czemuście Mnie szukali? Czy nie wiedzieliście, że powinienem być w tym, co należy do mego Ojca?” (Łk 2, 49) to również Jego pierwsze słowa, jakie wypowiedział przed rozpoczęciem publicznej działalności, a u Łukasza zarazem ostatnie z wypowiedzianych przez Syna do Matki ${ }^{36}$.

Można odnieść wrażenie, że Maryja zapomniała o słowie Boga, jakie skierowane zostało do Niej w momencie zwiastowania, a które dotyczyło Bożego synostwa Jezusa. Nawet po udzielonej przez Syna odpowiedzi, jak zanotował ewangelista, nadal nie rozumiała Jego słów. Dziwiła się Jego mądrości, którą okazywał podczas dyskusji z uczonymi. Pytaniem Matki zdziwiony był również Jezus. Stąd też, wydawałoby się, Jego niezbyt uprzejma odpowiedź. Swymi słowami potwierdza On jednak swoją jedność z Bogiem, który jest Jego Ojcem. Dlatego też nie tylko mógł, ale powinien przebywać w tym, co należy do Jego Ojca, a nikt inny, nawet Matka, nie może tego zmienić. Zarówno Maryi, jak i Józefowi została wcześniej objawiona prawda o mającym się narodzić w Betlejem Synu Najwyższego. Niewątpliwie więc znali oni prawdę o Jezusie, ale tylko w wymiarze ogólnym, bez konkretów i szczegółów dotyczących zbawczej misji Syna. Pytanie Maryi zadane Jezusowi w jerozolimskiej świątyni: „Synu, czemuś nam to uczynił?”, przypomina Jej wcześniejszą rozmowę z Gabrielem i podobne pytanie skierowane do niego: „Jakże się to stanie?". Maryja nie zapomniała więc o Bożej obietnicy, lecz pyta jedynie o sposób działania Boga, tak odmienny od działania ludzkiego $^{37}$. Dlatego dziwi się i dlatego nie rozumie. Jest to niewątpliwie

35 Zdaniem H. Langkammera jest to nawiązanie do biblijnej symboliki liczby dwanaście. Zob. Ewangelia wedtug św. Łukasza, tłum., wstęp, komentarz H. Langkammer, Lublin 2005, s. 81.

36 Zob. I. M. Calabuig, Maria e la speranza Cristiana. Prospettiva liturgica, [w:] Maria icona viva della chiesa futura, ed. C. Carvello, S. De Fiores, Roma 1998, s. 299-300.

37 Zob. G. Grossi, Maria custodiva e meditava la parola, Padova 2003, s. 133-134. 
przejaw Jej pielgrzymki wiary zapoczątkowanej w Nazarecie. Szukała Syna wśród krewnych i znajomych, czyli szukała Boga wśród ludzi. Znalazła Go w domu Ojca. Szukała Syna, a znalazła Boga, ponieważ Jezus jako jedyny Syn Ojca jest prawdziwym Bogiem, a jako jedyny Syn Maryi jest prawdziwym Człowiekiem ${ }^{38}$.

Motywy smutku i szukania Jezusa są charakterystycznymi dla Ewangelii według św. Łukasza aspektami paschalnymi. Całe wydarzenie miało miejsce w Jerozolimie, w której Jezus dokonał dzieła zbawczego. Po ukrzyżowaniu najbliżsi bezskutecznie szukali Go wśród umarłych. Maryja i Józef nie rozumieli tego, co dwunastoletni Jezus odpowiedział im w świątyni, gdzie znaleźli Go trzeciego dnia. Uczniowie również nie rozumieli słów Jezusa zapowiadających Jego mękę i śmierć, a nawet bali się Go pytać o to, co miałyby one znaczyć. Pojęli ich sens, gdy trzeciego dnia po śmierci spotkali Go żywego ${ }^{39}$. Maryja i Józef nie rozumieją odpowiedzi Jezusa nie w odniesieniu do Jego Bożego Synostwa, ale ze względu na zapowiedź tajemnicy paschalnej, zawartej w tej odpowiedzi („powinienem być w tym, co należy do mego Ojca"). Po wypełnieniu misji zbawczej Jezus przez śmierć i zmartwychwstanie wrócił do domu Ojca, którego obrazem była świątynia jerozolimska ${ }^{40}$. Maryja i Józef nie dostrzegli w odpowiedzi Jezusa owego wymiaru profetycznego i analogii pomiędzy triduum paschalnym a triduum bolesnych poszukiwań dwunastoletniego Syna. Pierwsze słowa Jezusa wypowiedziane na wzgórzu jerozolimskim korespondują z ostatnimi, wypowiedzianymi na wzgórzu Golgoty: „Ojcze, w Twoje ręce powierzam ducha mojego” (Łk 23, 46). Po powrocie do rodzinnego Nazaret, jak pisze ewangelista, „Matka Jego chowała wiernie wszystkie te wspomnienia w swym sercu" (Łk 2, 51). Jezus natomiast „czynił postępy w mądrości, w latach i w łasce u Boga i u ludzi" (Łk 2, 52). Postępowała też i dojrzewała wiara Maryi, którą bez zewnętrznej ekspresji i pytań okazała na Golgocie.

Właściwa postawa wobec Boga, uczenie się posłuszeństwa wobec Niego, potwierdzanego codziennym życiem i dojrzewanie wiary mimo rodzących się wątpliwości to zarówno przepowiedziany przez Symeona miecz przeszywający duszę Maryi, jak też kryterium

\footnotetext{
38 Zob. G. Grossi, Maria..., s. 134.

39 Zob. J. Kudasiewicz, Matka..., dz. cyt., s. 125.

40 Zob. J. Kudasiewicz, Matka..., dz. cyt., s. 125.
} 
przynależności do eschatologicznej rodziny Jezusa, wskazywane przez synoptyków (Mt 12, 46-50; Mk 3, 31-35; Łk 8, 19-21). Dojrzałość Jej wiary (już bez wątpliwości) najpełniejszy wyraz znalazła w milczącej obecności pod krzyżem umierającego Syna (J 19, 25-27) i w modlącej się wspólnocie wieczernika (Dz 1, 12-14) ${ }^{41}$.

\section{„Duch Święty zstąpi na Ciebie i moc Najwyższego osłoni cię". Duch Święty a Maryja}

W wiekach poprzedzających sobór watykański II w teologii Kościoła zachodniego pneumatologia nie cieszyła się wielkim zainteresowaniem. Biskup Alfons Nossol twierdzi nawet, że utrata wymiaru pneumatologicznego jest może najgłębszym kryzysem teologii współczesnej $^{42}$. Dzieje się tak prawdopodobnie dlatego, że Duch Święty jest najbardziej tajemniczą ze wszystkich Trzech Osób Boskich. Syn Boży ukazał się w ludzkiej postaci i dlatego możemy sobie tworzyć jakiś obraz Ojca, którego Syn objawił. Natomiast w świetle danych objawienia Duch Święty jest niewyobrażalny. Z tego też powodu bardzo często nazywany jest On Bogiem nieznanym albo zapomnianym. Zachodniej Tradycji Kościoła zarzuca się często, że zapomniała o Duchu Świętym. Mariologia tej samej Tradycji nie obawia się jednak, według teologów reformowanych, zastępowania Ducha Świętego Maryją ${ }^{43}$. Sobór Watykański II, jakkolwiek nie poświęcił pneumatologii żadnego dokumentu, wskazał jednak na dynamizm Jego obecności i działania w Kościele ${ }^{44}$. On bowiem, według świadectwa Biblii, to „Pocieszyciel, Duch Święty, którego Ojciec pośle w moim imieniu, On was wszystkiego nauczy i przypomni wam wszystko, co Ja wam powiedziałem" (J 14, 26). Przywołując nauczanie św. Ambrożego, według którego Maryja jest typem Kościoła, w którym zgodnie

${ }^{41}$ Zob. Mary in the New Testament, ed. R. E. Brown J. A. Fitzmyer, K. P. Donfired, New York 1978, s. 154-157.

42 A. Nossol, Wprowadzenie, [w:] Wokót tajemnicy Ducha Świętego. Materiały Seminarium Wyktadowców Dogmatyki. Góra Świętej Anny 20-21.10.1998, red. P. Jaskóła, Opole 1998, s. 5 (Sympozja, 27).

43 Zob. R. Laurentin, Esprit Saint et theologie mariale, „Nouvelle Revue Théologique” 89 (1987), s. 26-31.

44 Zob. Y. M. J. Congar, Wierze w Ducha Świętego, t. I, Duch Święty w „ekonomii”. Objawienie i doświadczenie Ducha, tłum. A. Paygert, wstęp S. C. Napiórkowski, s. 187-193. 
z zapowiedzią Chrystusa obecny jest i działa Duch Święty, skoncentrujemy ostatnią część naszych rozważań na relacjach Ducha Świętego i Maryi, przedstawiając konkretne aspekty tych zależności.

\section{Oblubienica w Duchu i ikona Ducha Świętego}

W czasach mesjańskich, czyli od momentu wcielenia po powtórne przyjście Chrystusa, a konkretnie w zmartwychwstaniu, Duch Święty, używając terminologii biblijnej, „wylany został na każde ciało” (Dz 2,17). Zmartwychwstały Pan jest odtąd jedynym i powszechnym pośrednikiem między Bogiem a ludźmi. Duch Święty natomiast jednoczy odkupionego z Odkupicielem, dzięki czemu wytwarza się synowska relacja z Bogiem Trójosobowym. Człowiek ma zatem dostęp do Ojca przez Chrystusa i w Duchu Świętym ${ }^{45}$. Obecność i działalność Ducha Świętego są bardziej dyskretne i tajemnicze niż publiczna działalność historycznej postaci Jezusa i Jego obecność w Kościele. Niewątpliwie owa dyskrecja miała swój wpływ na mówienie o Duchu Świętym jako o Bogu zapomnianym. Ponowne odkrycie Trzeciej Osoby Boskiej zwłaszcza w kontekście chrystologii, soteriologii, eklezjologii i mariologii wyleczyło, zdaniem Francesco Lambiasiego, teologię katolicką z tak zwanej „anemii pneumatologicznej”46.

W mariologii ludowej osoba Maryi porównywana jest do Arki Przymierza, na którą zstępuje obłok obecności Ducha, a chwała Pana napełnia ten przybytek (zob. Łk 1, 35; Wj 40, 35). Bóg, który zstępuje na Synaj, by w swoim Duchu zamieszkać w Arce Przymierza, a następnie w świątyni, zstępuje też na Maryję, by zamieszkać w Jej łonie $^{47}$. Jakkolwiek porównanie to jest przejawem wiary ludowej, to jednak uzasadnienie teologiczne jest przekonujące. Po zwiastowaniu Maryja udaje się bowiem „z pośpiechem” do domu Zachariasza i Elżbiety, by odwiedzić swą krewną, która, o czym dowiedziała się podczas zwiastowania, oczekuje dziecka, mimo że jest już w wieku podeszłym. Wizyta ta przypomina obrzęd przeniesienia Arki Przymierza

45 Zob. F. Lambiasi, Lo Spirito Santo: mistero e presenza. Per una sintesi di pneumatologia, Bologna 1987, s. 217.

46 Zob. F. Lambiasi, Lo Spirito Santo..., dz. cyt., s. 11-18.

47 Zob. A. Serra, Aspetti mariologici della pneumatologia di Lc 1,35, [w:] „Maria e lo Spirito Santo". Atti del IV Simposio Mariologico Internazionale" (Roma 1982), RomaBologna 1984, s. 152. 
z domu Abinadaba do Obed-Edoma z Gat, a następnie do Jerozolimy (2 Sm 6, 1-11). Zarówno Arka Starego Przymierza, jak i Maryja, Arka Nowego Przymierza, przemierzają tę samą górzystą krainę Judy. Przeniesienie Arki jest przyczyną radości narodu wybranego. Wizyta Maryi u oczekującej narodzin Elżbiety wywołuje mesjańską radość u rodziców Poprzednika Chrystusa. Jego matka wyraża ją nawet pytaniem: „A skądże mi to, że matka mojego Pana przychodzi do mnie?" (Łk 1,43$)$. W podobny sposób, choć w innych okolicznościach, zareagował Dawid podczas przenoszenia Arki: „Jakże przyjdzie do mnie Arka Jahwe?" (2 Sm 6, 9). Pobyt Maryi w domu Zachariasza trwał trzy miesiące (Łk 1,56). Również pobyt Arki w domu Obed-Edoma przeciągnął się do około trzech miesięcy. Istnieje jednak istotna różnica. O ile bowiem Arka Przymierza wyrażała jedynie miejsce obecności Boga i Jego mieszkanie, o tyle Maryja jest rzeczywistym miejscem i mieszkaniem Boga, którego nosiła w swoim łonie przez dziewięć miesięcy ${ }^{48}$. Odwieczny Bóg staje się bliski człowiekowi, ofiarowując mu w miłości Stwórcy i Odkupiciela swoją zbawczą miłość, przez co jest Emmanuelem, „Bogiem z nami”. W Duchu wypełnia się zatem tajemnica Przymierza jako spotkania, umowy i wymiany darów. Bóg jako ten, który ukochał, jednoczy się z tym, którego ukochał w wewnętrznej perychorezie życia Bożego.

Teologia określa Maryję jako Oblubienicę Ducha Świętego, a nawet Oblubienicę Trójcy Świętej ${ }^{49}$. Teologia Ducha, dzięki której Chrystus otrzymał pełnię Ducha Świętego (zob. Mt 3, 16; Mk 1, 10; Łk 3, 22; J 1, 33), łączy się ściśle z teologią Słowa, według której Duch Święty jest tym, który kontynuuje dzieło Chrystusa (J 14, 26; Dz 1, 5; 2, 38; Rz 8, 9; Gal 4, 6) i zaangażowany jest w dzieło Nowego Przymierza. W teologii Słowa to Maryja jawi nam się jako Oblubienica eschatologicznych zaślubin między Bogiem a Jego ludem i Duchem Świętym, który na Niej spoczął jako na reprezentantce nowego ludu Bożego, aby wypełnić nowe i wieczne Przymierze w krwi Chrystusa $^{50}$ (Mt 26, 28; Mk 14, 24; Łk 22, 20; 1 Kor 11, 25). W czym wyraża się zatem relacja między Matką Pana a Duchem Świętym w kontekście tajemnicy Przymierza? Odpowiedź nie jest prosta, trzeba tu

\footnotetext{
48 Zob. S. Manelli, Mariologia..., dz. cyt., s. 196.

49 Zob. B. Forte, Maria..., dz. cyt., s. 237.

50 Zob. B. Forte, Maria..., dz. cyt., s. 238.
} 
bowiem przywołać odniesienie do wyznania wiary, które odwołuje się do narodzenia Jezusa z Ducha Świętego i Maryi Dziewicy ${ }^{51}$. Pavel Evdokimov pisze w powyższym kontekście: „Istnieje tajemnicza zgodność milczenia trzech pierwszych wieków odnośnie do Ducha Świętego i Dziewicy, ale ich podwójna kenoza osiągnęła punkt kulminacyjny w decyzjach Magisterium Kościoła IV i V wieku"52. Wyznając wiarę w bóstwo Ducha Świętego, a Maryję nazywając Bożą Rodzicielką, Kościół wypowiedział się jednoznacznie i stanowczo przeciwko redukcjonizmom i herezjom, które negowały wcielenie Syna Bożego i Jego wiecznie trwającą aktualność zbawczą, zagwarantowaną obecnością Ducha Świętego ${ }^{53}$. W wiekach późniejszych relacja Duch Święty a Maryja uległa mocnemu zniekształceniu na niekorzyść Trzeciej Osoby Boskiej. Teologowie, a nawet święci apostołowie maryjni odbierali często Duchowi Świętemu wiele tytułów i funkcji Jemu właściwych, a przypisali je Maryi. Laurentin wymienia niektóre z nich: „Maryja jest Matką miłosierdzia”, „Przez Maryję do Jezusa”, „Maryja kształtuje w nas Chrystusa”, „Maryja jest naszym natchnieniem i Matką dobrej rady”, "Maryja jest pomostem między nami a Chrystusem" ${ }^{44}$. Nawet przedstawiciel teologii wyzwolenia, którym jest niewątpliwie Leonardo Boff, skądinąd krytycznie nastawiony do mariologii Kościoła rzymskokatolickiego, w Macierzyńskim obliczu Boga pisał: „Duch Święty na sposób prawdziwy i rzeczywisty uczynił z Maryi swoją świątynię, swoje sanktuarium, swoje tabernakulum, przez który to fakt jest Ona zjednoczona hipostatycznie z Trzecią Osobą Trójcy Świętej” ${ }^{55}$. Teologowie nie mogą jednak zapominać, że Maryja jest świątynią Boga, a nie Bogiem świątyni. Bóg zawiera Przymierze z człowiekiem, który staje się Jego partnerem. To jednak nie oznacza, że wchodzi z Nim w relację zjednoczenia hipostatycznego. Przymierze ukierunkowane jest na zbawienie człowieka, którego stworzył Bóg, a który wypowiedział Mu posłuszeństwo. W realizacji tego zamysłu Stwórca posługuje się człowiekiem, z którym zawarł Przymierze, aby jedyny Pośrednik i Odkupiciel z niego mógł

51 Por. Enchiridion symbolorum definitionum et declarationum de rebus fidei et morum [dalej: DS], Barcinione $1973^{36}, 10$.

52 Zob. P. Evdokimov, La donna e la salvezza del mondo, Milano 1980, s. 197.

53 Zob. B. Forte, Maria..., dz. cyt., s. 239.

54 R. Laurentin, Esprit Saint et théologie mariale, dz. cyt., s. 27.

55 L. Boff, Il volto materno di Dio, Brescia 1981, s. 93 [tłum. własne - W. Ż.]. 
wziąć ludzkie ciało i stać się człowiekiem. Zbawienie jest Jego dziełem, nie jest samozbawieniem. Nie ma innych współodkupicieli. Teologia, opierając się na danych objawienia, musi zawsze eksponować Bożą transcendencję i zwierzchność. W Przymierzu jednak zobowiązują: wolność i miłość, wybranie, powołanie i odpowiedź. W przypadku Maryi wszystkie te wymogi zostały zrealizowane.

Opisując te tajemnice wiary, teologia posługuje się językiem oddającym rzeczywistość ziemską - pojęciami: miłość, wierność, przymierze małżeńskie, przymierze oblubieńcze, gdzie miłość i wierność stanowią istotę wspólnoty Przymierza i zjednoczenia. Współczesna teologia wydaje się odchodzić od kategorii „Oblubienicy Ducha” na rzecz „Oblubienicy w Duchu”, a jako takiej - „Ikony Ducha Świętego”. W tymże Duchu Maryja przyczynia się do tego, że na ziemi możemy widzieć Boga, a w konsekwencji człowieka wobec Boga, co wynika z Przymierza ${ }^{56}$. Dziewica-Matka, Oblubienica w Duchu jawi się nam więc jako ikona Ducha Świętego. On sprawia w Niej to, co w wieczności i całej ekonomii zbawczej sprawia Bóg Ojciec. Z faktu bycia Maryi Oblubienicą w Duchu i ikoną Ducha Świętego wynikają konsekwencje, nad którymi musi Ona się pochylić. Pierwszą jest Jej świętość. Wynika ona z obfitości łaski, którą Bóg Ją obdarował i z postawy zawsze współpracującą z łaską. Kiedy spotykają się łaska i wiara, to, co Boże, z tym, co ludzkie, obecny jest zawsze Duch Święty ${ }^{57}$. Obdarowanie Maryi przez wszechmocnego Boga pełnią łaski ujawnia swego rodzaju dialektykę między zwierzchnością Boga a historycznymi uwarunkowaniami człowieka. Pełnia łaski, jaką Bóg obdarował Maryję, oznacza w języku Biblii potwierdzenie doniosłości Jej Bożego macierzyństwa jako wydarzenia historiozbawczego, a zarazem Jej osobistej decyzji. Decyzja ta, jak świadczy Biblia, była pozytywna.

Druga konsekwencja to Jej stan chwały. Jeśli bowiem świętość Maryi objawia nam tajemnicę wzajemności w miłości i wierności Boga i człowieka, to wynika $\mathrm{z}$ tego tajemnica antycypacji albo też zrealizowanej już nadziei. Bóg był zawsze wierny swoim obietnicom.

56 Zob. P. Evdokimov, La donna..., dz. cyt., s. 209.

57 „Nic dziwnego, że przyjął się u świętych Ojców zwyczaj nazywania Bogarodzicy całą świętą i wolną od wszelkiej zmazy grzechowej, jakby utworzoną przez Ducha Świętego i ukształtowaną jako nowe stworzenie". Sobór Watykański II, Konstytucja dogmatyczna o Kościele Lumen gentium, [w:] Sobór Watykański II. Konstytucje, dekrety, deklaracje, Poznań 2002, 56. 
W przypadku Maryi, reprezentantki ludzkości, wiernym okazał się również człowiek. Wypełnione zostało Przymierze i to z Synaju, i to z Nazaretu, potwierdzone w wieczerniku i na Golgocie ${ }^{58}$. Jako Dziewica jest więc Ona ikoną Syna, jako Matka jest ikoną Ojca, natomiast jako Oblubienica w Duchu jest ikoną Ducha Świętego. Bóg posłużył się bowiem Maryją, aby objawić światu siebie, swoje oblicze. Ona ukierunkowuje nas ku Transcendencji wkraczającej w immanentność świata. Zdaniem Brunona Fortego fakt, że Maryja jest ikoną Boga Trójosobowego, wypływa z Jej szczególnej relacji jednocześnie do Boga, do Kościoła i do człowieka ${ }^{59}$. Bóg Ojciec staje się w Maryi rozpoznawalny z tego względu, że to Ona ukazuje tajemnicę odwiecznego rodzenia Syna przez Ojca. Rodząc w "pełni czasów” tego samego Syna, którego Ojciec rodzi odwiecznie, Maryja jest ikoną macierzyńską ojcostwa Boga albo, wyrażając się inaczej, ikoną ludzką ojcostwa Bożego ${ }^{60}$. Jako pierwsza uczennica Syna i pierwsza chrześcijanka, Matka, która pozostała Dziewicą, jest także ikoną Bożego i Jej Syna. Wyraża bowiem postawę Osoby odwiecznie kochanej (Syn) wobec Tego, który odwiecznie kocha (Ojciec) ${ }^{61}$. Oblubieńcza rola Maryi w perspektywie historiozbawczej wynika z faktu, że jest Ona reprezentantką narodu wybranego, zawsze wierną wymogom Przymierza. Jest Oblubienicą, reprezentującą w „pełni czasów” i podczas zaślubin (J 2,1-12) nowy już lud Boży, czyli Kościół, przez co dokonało się Nowe Przymierze we krwi Chrystusa ${ }^{62}$.

Jako Oblubienica Ojca i Syna Maryja jest ikoną w Duchu Świętym. Bruno Forte tezę tę uzasadnia następująco:

Maryja jest Matką Dziewicą, stworzeniem, w którym Przedwieczny poślubił historię, w Przymierzu, które łączy to, co ludzkie, z tym, co Boskie, ziemię z niebem. Tajemnica to oblubieńcza, której Ona jest zarówno miejscem jak i bohaterką oraz świadkiem [...] wynika z tego, że w refleksji wiary

\footnotetext{
58 Zob, B. Forte, Maria..., dz. cyt., s. 244.

59 B. Forte, Maria..., dz. cyt., s. 18.

60 B. Forte, Maria..., dz. cyt., s. 207.

${ }^{61}$ Zob. G. M. Bartosik, Maryja ikona Ducha Swiętego wedtug Bruno Forte, [w:] „Duch Święty a Maryja." Materiały z sympozjum zorganizowanego przez Katedrę Mariologii KUL oraz Oddział PTT w Częstochowie 22-23 maja 1998, red. S. C. Napiórkowski i in., Częstochowa 1999, s. 154.

62 G. M. Bartosik, Maryja..., dz. cyt., s. 160.
} 
dostrzeżono w Maryi w sposób najdoskonalszy Oblubienicę, w której realizuje się obietnica Nowego Przymierza ${ }^{63}$.

Stary Testament przedstawiał Przymierze zawarte przez Boga z narodem wybranym w kategoriach relacji oblubieńczej, wierności, miłości i zaufania. Można więc powiedzieć, że w Maryi realizuje się starotestamentalne proroctwo wypowiedziane przez Izajasza: „Albowiem spodobałaś się Panu i twoja kraina otrzyma męża. Bo jak młodzieniec poślubia dziewicę, tak twój Budowniczy ciebie poślubi, i jak oblubieniec cieszy się z oblubienicy, tak Bóg twój tobą się rozraduje" (Iz 62, 4-5) ${ }^{64}$.

Tradycja Kościoła odczytywała oblubieńczy wymiar misji Maryi w kategoriach tytułów: „Oblubienica Boga”, „Oblubienica Ojca”, „Oblubienica Chrystusa”, „Oblubienica Ducha Świętego”. Ta różnorodność wyrażeń, zdaniem Fortego, ujawnia wielkie bogactwo tajemnicy wybrania i łaski, która dokonała się w Matce Chrystusa. Dlatego proponuje on zrezygnowanie z nazywania Maryi Oblubienicą konkretnej Osoby Boskiej z tego względu, że najpierw należałoby określić kryterium oblubieńczości. Stawia zatem pytanie, do której z Osób Boskich odnosi się bezpośrednio to, co jest określane symboliką oblubieńczą ${ }^{65}$. Jego zdaniem tajemnicę oblubieńczej relacji najlepiej wyraża bowiem Osoba Ducha Świętego, ponieważ:

Ten, który łączy obdarzającego Ojca z obdarowanym Synem i w Nim i przez Niego z całą ludzką naturą, stanowi węzeł miłości w najgłębszej głębi tajemnicy Boga, który jest jednocześnie Jego węzłem miłości ze światem [...] to jest właśnie Duch Święty. To w Nim w sposób najpełniejszy dokonuje się tajemnica przymierza jako spotkania, paktu i wzajemnego daru. On łączy Kochającego z Kochanym w wewnętrznej perychorezie [...]. W Duchu Świętym Bóg wychodzi poza siebie ${ }^{66}$.

Zgodnie z powyższą sugestią Fortego, Matka Pana jest Oblubienicą, która podczas zaślubin (Nazaret, Betlejem, Kana, Golgota)

\footnotetext{
63 B. Forte, Maria..., dz. cyt., s. 231 [tłum. własne - W. Ż.].

64 B. Forte, Maria..., dz. cyt., s. 231.

65 B. Forte, Maria..., dz. cyt., s. 237.

66 B. Forte, Maria..., dz. cyt., s. 235-236 [tłum. własne - W. Ż.].
} 
w „pełni czasów” reprezentuje ludzkość wobec Boga. Duch Święty zstępuje na Nią jako na przedstawicielkę nowego ludu Bożego, aby dokonać Nowego Przymierza ${ }^{67}$.

W powyższej perspektywie Bruno Forte, teolog doby posoborowej, biskup Kościoła i w przeszłości przewodniczący Papieskiej Międzynarodowej Akademii Maryjnej zauważa, że w odniesieniu do wzajemnych relacji między Trzecią Osobą Boską a Maryją teologicznie bardziej uzasadnione jest sformułowanie Oblubienica w Duchu Świętym, ponieważ:

Oblubieńczość Maryi objawia się jako relacja oblubieńcza w Duchu Świętym: w Nim Ona łączy się z Ojcem i Synem, w Nim Ona uczestniczy w płodności Jednego i zdolności przyjmowania Drugiego, w Nim Ona staje się Arką Przymierza, która łączy niebo z ziemią, strzegąc Boga w ludzkim ciele. Oblubienica w Duchu Świętym objawia się jako całkowicie przejrzysta dla Jego działalności oblubieńczej [...]. W Duchu Świętym Maryja rodzi formę Boską na ziemi i formę ludzką w niebiosach: w Nim Ona jest bramą Boga na świat i bramą świata w kierunku Boga ${ }^{68}$.

Istnienie Maryi jako ikony w Duchu Świętym w sposób najbardziej czytelny przemawia do nas w tajemnicy Jej świętości i chwalebnego uwielbienia poprzez wniebowzięcie. „Świętość Maryi to spotkanie oblubieńcze między «tak» Boga a «tak» Matki Jego Syna [...] spotkanie, które dokonało się w Duchu Świętym, ukazując cud wzajemności w łasce między Stworzycielem a stworzeniem"69.

\section{Mocą szczególnej łaski i przywileju poczęta, w sposób szczególny odkupiona}

Nowy Testament jednoznacznie poświadcza w wielu swoich tekstach oblubieńczy wymiar Ducha Świętego, ukazujący Chrystusa jako Tego, który otrzymuje Ducha Świętego od Ojca (Mt 3, 16; Dz 2, 33; 10, 38; J 16, 14-15; 19, 30). Ten sam Duch, zapowiedziany przez Chrystusa, posłany jest po to, aby aktualizował Przymierze

\footnotetext{
67 Zob. G. M. Bartosik, Maryja..., dz. cyt., s. 160.

68 B. Forte, Maria..., dz. cyt., s. 161 [tłum. własne - W. Ż.].

69 B. Forte, Maria..., dz. cyt., s. 162 [tłum. własne - W. Ż.].
} 
wypełnione przez Chrystusa, przypominał wszystko, czego nauczał Jezus, czynił ludzi dziećmi Bożymi i prowadził ich do pełnej prawdy (J 14, 26; Dz 1, 5; 2, 38; Rz 8, 9; Ga 4, 6). Jeśli zatem istnieje prawda o Pocieszycielu, Duch Świętym, którego Ojciec pośle w imieniu Jezusa, a który wszystkiego nas nauczy i przypomni nam wszystko, co Jezus nam powiedział (zob. J 14, 26), to również doktryna o niepokalanym poczęciu Maryi i Jej chwalebnym wzięciu do nieba znajduje swe uzasadnienie w doktrynie objawionej.

„Gdy zaś przyjdzie On, Duch Prawdy, doprowadzi was do całej prawdy. Bo nie będzie mówił od siebie, ale powie wszystko, cokolwiek usłyszy, i oznajmi wam rzeczy przyszłe. On Mnie otoczy chwałą, ponieważ z mojego weźmie i wam objawi” (J 16, 13-14). Dlatego też trzeba interpretować w kontekście powyższych słów dwa ostatnie orzeczenia Magisterium Kościoła mające status dogmatyczny: o niepokalanym poczęciu Maryi (1854) i Jej chwalebnym wzięciu do nieba (1950). Teologia protestancka, a nawet katolicka zarzuca tym orzeczeniom brak podstaw biblijnych. To prawda, że w Nowym Testamencie brak jest konkretnych tekstów maryjnych, które doktrynę tę jasno by uzasadniały. Prawdą jest też, że teologiczna (i nie tylko) droga prowadząca do definicji dogmatycznej niepokalanego poczęcia Maryi była długa i znaczona decyzjami nieraz dramatycznymi (ślub krwi). Bulla Ineffabilis Deus dogmatyzująca niepokalane poczęcie Maryi, odwołując się do aktualnej wiary Kościoła i pobożności wiernych, stwierdza odwieczne przeznaczenie Maryi do Bożego macierzyństwa, pełni łaski i wolności od grzechu. Pius IX rozstrzyga tym samym trwające wiele wieków spory dotyczące kwestii teologicznych: wyjęcia Maryi spod prawa grzechu pierworodnego mimo jego powszechności i odkupienia Dziewicy przed wypełnieniem przez Chrystusa dzieła zbawczego. Owo rozstrzygnięcie dokonane zostało dzięki zastosowaniu terminologii teologicznej: mocą szczególnej łaski i przywileju wszechmocnego Boga, mocą przewidzianych zasług Jezusa Chrystusa, Zbawiciela rodzaju ludzkiego, została nietknięta od wszelkiej zmazy grzechu pierworodnego ${ }^{70}$.

Dogmat ten, jakkolwiek dotyczy osoby Matki Odkupiciela, przede wszystkim potwierdza powszechność odkupienia dokonanego przez Chrystusa i powszechność grzechu pierworodnego. Jawi się zatem 
jako swoistego rodzaju znak, w Duchu Świętym dany przez Boga wspólnocie kościelnej i potwierdzający wierność Ojca danym wcześniej obietnicom. Konkretnie więc jest to znak miłości i wierności Boga wobec człowieka. Poprzez niepokalane poczęcie Maryi Bóg Ojciec potwierdza realizację wcześniejszych zapowiedzi, spełnienie ludzkich nadziei i oczekiwań. Tak jak początek każdego człowieka jest w Bogu, tak też w Nim jest jego koniec ${ }^{71}$. Bóg obdarza człowieka tak wielką miłością (która rozlana jest w sercach naszych przez Ducha Świętego), że przeznacza go do wiecznej chwały już wtedy, gdy ten dopiero w Bożym zamyśle udzielił odpowiedzi. Maryja została zachowana jako wolna od grzechu pierworodnego nie mocą własnych zasług, ale dzięki miłosierdziu Boga, ze względu na przyszłe zasługi Syna ${ }^{72}$. Niepokalane poczęcie jest też znakiem odkupieńczej miłości Chrystusa. Prewencyjne odkupienie Maryi poprzez przywilej i łaskę niepokalanego poczęcia jest potwierdzeniem centralnej roli Chrystusa w dziele zbawczym. Dogmat ten potwierdza bowiem, że odkupienie dokonane przez Chrystusa ukierunkowane jest na zmianę relacji człowieka wobec Boga nie tylko w wymiarze jurydycznym czy ontologicznym, ale również dlatego, że człowiek staje się nowym stworzeniem. Ostatnie słowo należy bowiem nie do grzechu, ale do Chrystusa $^{73}$. Po trzecie, niepokalane poczęcie jest znakiem obecności i działania Ducha Świętego w Kościele. Jeśli zgodnie ze świadectwem ewangelisty Jana $(J 14,26 ; 16,13)$ Duch Święty dopełnia dzieła Chrystusa, to w Maryi owo dopełnienie zapoczątkowane zostało już w momencie Jej poczęcia. Maryja należy do Boga. Udzielona Jej wtedy łaska oznacza samego Boga. Łaska oznacza też wolność, rękojmię życia wiecznego, działanie Ducha Świętego w człowieku nią obdarowanym. Niepokalane poczęcie oznacza zatem, że w Maryi (a dzięki Niej również w nas) wszystko jest łaską Boga, że do Niego należymy. W nas, tak jak w Maryi, jest obecny i działa ten sam Duch Święty, który pozwala nam wzrastać $\mathrm{w}$ świętości ${ }^{74}$. Znak ten potwierdza zwycięstwo nad grzechem pierworodnym, które możliwe jest

71 Zob. K. Rahner, Maria, Madre del Signore, Fossano 1962, s. 44.

72 Zob. K. H. Menke, Incarnato nel seno della Vergine Maria. Maria nella storia di Israele e nella Chiesa, Milano 2002, s. 177-178.

73 Zob. K. Rahner, L'Immacolata Concezione. Saggi di Cristologia e Mariologia, Roma 1965, s. 429-430.

74 Zob. A. M. Calero, La Vergine Maria..., dz. cyt., s. 208. 
w przypadku człowieka otwartego na Bożą łaskę. Wskazuje też na początek nowego świata, ożywianego przez Ducha Świętego i na odzyskaną przez człowieka godność synostwa Bożego, utraconą przez grzech pierworodny ${ }^{75}$.

Skoro niepokalane poczęcie jest znakiem obecności i działania Ducha Świętego w Kościele, gdyż to trzecia Osoba Trójcy Świętej dopełnia dzieła Chrystusa, to w Maryi owo dopełnienie jako efekt działalności Ducha Świętego wypełniło się w tajemnicy Jej Wniebowzięcia. Bóg, który był z Nią obecny już w momencie poczęcia, był też obecny, jak podaje konstytucja apostolska Munificentissimus Deus, w Jej godzinie wypełnienia życia ziemskiego. Kościół dostrzega w Maryi doskonały owoc świętości, który jest efektem działania Ducha Świętego, przyjętego przez Nią w sposób wolny. Jest wzięta do nieba, czyli w pełni odkupiona, co dokonało się przez niepokalane poczęcie jako osobista łaska i przywilej ze względu na przyszłe zasługi Bożego i Jej Syna. Duch Święty, jednocząc Ojca z Synem, a człowieka przez Syna i w sobie z Ojcem sprawia, że Matka Pana w chwale wniebowzięcia reprezentuje już Kościół chwalebny, do którego ten ziemski dopiero zmierza ${ }^{76}$. Ludzka ikona Bożego ojcostwa i zarazem macierzyństwa dostąpiła już wiecznych zaślubin między Tym, który odkupił Ją przez łaskę i przywilej niepokalanego poczęcia a Jego ludem, którym jest Kościół. W Jej osobistym przeznaczeniu zrealizowane jest już to, co w oblubieńczym Przymierzu obiecane zostało wszystkim odkupionym ${ }^{77}$. Michele Giulio Masciarelli, profesor dogmatyki w rzymskim Marianum, uzasadnia chwałę Maryi, w której zrealizowane zostało już przeznaczenie-obietnica złożona wszystkim ludziom, Jej wyjątkową świętością. Świętość tę nazywa oblubieńczym spotkaniem między „fiat” Boga wobec Maryi i „fiat” Maryi wobec Boga. Spotkanie to dokonało się w Duchu Świętym jako owoc Jego obecności i działalności ${ }^{78}$. O ile jednak

75 Zob. S. De Fiores, Immacolata, [w:] Nuova Dizzionario di Mariologia, ed. S. De Fiores, S. Meo, Roma 1985, s. 702.

76 Zob. S. De Fiores, Maria partecipe della gloria di Cristo risorto. Apporti e prospettive, [w:] L'Assunzione di Maria Madre di Dio. Significato storico-salvifico a 50 anni dalla definizione dogmatica, ed. G. C. Moralejo, S. Cecchin, Città del Vaticano 2001, s. 687.

77 Zob. B. Forte, Maria..., dz. cyt., s. 245.

78 M. G. Masciarelli, Maria icona perfetta dell'umanità pervenuta per grazia al suo compimento, [w:] L'Assunzione di Maria Madre di Dio..., dz. cyt., s. 422. 
niepokalane poczęcie jest łaską i przywilejem udzielonym Maryi przez Wszechmogącego Boga, o tyle Jej wzięcie do chwały niebios jest potwierdzeniem skuteczności zbawczego dzieła Chrystusa i zachętą do nadziei, że dana nam przez Boga obietnica, która spełniła się wobec Maryi, tak samo spełni się wobec nas.

\section{Zakończenie}

Teologia po Soborze Watykańskim II w odniesieniu do mariologii w kontekście trynitologii, stosując się do wskazań Soboru, w rozważaniach swych wróciła do opracowań ojców Kościoła, w których dogmat mariologiczny rozważany był w ścisłym kontekście $\mathrm{z}$ dogmatem trynitarnym. Adhortacja apostolska Pawła VI Marialis cultus jednoznacznie potwierdza, że rozważania dotyczące Maryi muszą czerpać swe źródło z teologii trynitarnej. Maryja jest bowiem umiłowaną córką Ojca, Matką Bożego Syna i Świątynią Ducha Świętego. To Ją Bóg osłania mocą swojego Ducha. Trójosobowy Bóg swą bezinteresowną i łaskawą wobec stworzenia, jakim jest Maryja decyzją, czyni z Niej namiot spotkania z ludzkością, której odkupienia pragnie ${ }^{79}$. Bóg wybrał, powołał i przeznaczył Ją na bycie Matką swego Syna po to, by w ten sposób objawić światu swe ojcowskie oblicze ${ }^{80}$. Jako Matka jest więc Ona ikoną ojcostwa Bożego. Jako Matka, która pozostała Dziewicą, jest ikoną Syna. Jako Oblubienica w Duchu jest ikoną Ducha Świętego. Odkupiona w sposób szczególny poprzez przywilej niepokalanego poczęcia, osiągnęła już stan chwały niebieskiej, co wyraża dogmat o Wniebowzięciu, wskazując Kościołowi realizm i skuteczność odkupienia dokonanego przez Boga w Chrystusie, a dopełnianego w Duchu Świętym. Tajemnica Maryi (dogmat maryjny) znajduje więc swe uzasadnienie i wyjaśnienie w świetle „Tajemnicy Tajemnic”, jaką jest dogmat trynitarny.

79 Zob. M. Masini, Maria di Nazaret..., dz. cyt., s. 274.

80 Zob. E. Ozorowski, Czy traktat o Trójcy Przenajświętszej może się obejść bez nauki o Maryi?, [w:] Trójca Święta a Maryja. Materiały z sympozjum mariologicznego..., dz. cyt., s. 10. 


\section{Summary}

\section{The Marian dogma in the context of the trinitarian dogma. An intertwined historic and saviour perspective}

The special grace that God bestowed upon Mary, as well as Her destiny to be the Mother of His Son, not only allowed Her active participation in the salvation work, but also created a special relationship between the teenage girl from Nazareth and the Trinitarian God. Each human, in the person of Mary, became the partner of God. The New Covenant, initiated in Nazareth, has been confirmed by Christ's blood at Calvary. From that moment on, each human is not only God's partner but also ,a son in His Son". Thus, the mystery of the Trinity explains also the mystery of the Virgin Mary, who remained a virgin even when by the will of the Father and through the Holy Spirit she became the Mother to the Son of God. Neither theology, nor Christian faith make Mary a superhuman, or assign Her with divine qualities. She is rather perceived as the first of the redeemed by grace and the privilege of Immaculate Conception (with the view to subsequent merits of Christ's Passion, His death and resurrection), who having accomplished Her earthly life within the powers of the Holy Spirit, had found the glory of the saved.

God had chosen and called Mary to reveal His face to human, the face of the merciful Father. In the fullness of time, the Trinity entered the history of mankind. Henceforth, the immanence of both the world and human can experience, see and touch the divine transcendence. God the Father is visible in Mary, as she appears to visualise the eternal mystery of the birth of the Son by the Father in the most perfect manner. The very Son is born by her in due time, thus she as the mother, becomes the maternal icon of the fatherhood of God. It is Him who sent His Word to the world and to the history of mankind, to renew the covenant with the Chosen People. The church by considering her maternal mission to God's Son, to which she was called by Her Father, sees Mary as "the most beloved daughter of the Father and the Shrine of the Holy Spirit".

Mary's virginity is primarily a sign of her fidelity and obedience to God. In the Old Testament the term „virgin” was, however, referred to the Chosen People preserving the fidelity to the promises of the Covenant. Israel lost its virginity when they forgot the obligations arising from the Covenant. In the Annunciation Mary is shown as a representative of the rest of Israel, which has remained faithful to the Covenant. Hence, the Virgin is an icon of the Son of the Father, the Son equal and faithful to Him, whereas in Christ, the Virgin represents the icon of the virginal maternal Church.

The third person of the Trinity is the key to clarifying the mystery of brideship rooted in the Covenant, with reference to Marian and Trinitarian relations. These 
relationships, however, shall not be treated on the level of Mary being equal to the Three Divine Persons. Primacy and initiative are always God's acts. It is Him who acts, chooses, appoints, or bestows grace that the Bride in the Holy Spirit, the icon of the greatest works of the Father, delivered by Christ in the Holy Spirit, personally experienced. It was Her, the redeemed by Immaculate Conception, the first Christian to have experienced the glory of the saved by the Assumption.

Keywords: dogma of Mary, dogma of the Holy Trinity, Holy Spirit, mariology

\section{Bibliografia}

Amato A., La SS Trinita e Maria. Sintesi teologica, [w:] I. de la Potterie, Come collaborare al progetto di Dio con Maria. Principi e proposte, Roma 1985, s. 9-39 (Mater Ecclesiae. Serie Pastorale, 11).

Bartosik G. M., Maryja ikona Ducha Świętego wedtug Bruno Forte, [w:] „Duch Święty a Maryja". Materiały z sympozjum zorganizowanego przez Katedre Mariologii KUL oraz Oddziat PTT w Częstochowie 22-23 maja 1998, red. S. C. Napiórkowski i in., Częstochowa 1999, s. 149-165.

Bertalot R., Ecco la Serva del Signore. Una voce protestante, Roma 2002.

Boff L., Il volto materno di Dio, Brescia 1981.

Calabuig I. M., Maria e la speranza Cristiana. Prospettiva liturgica, [w:] Maria icona viva della chiesa futura, ed. C. Carvello, S. De Fiores Roma 1998, s. 291-308.

Calero A. M., La Vergine Maria nel mistero di Cristo e della Chiesa. Saggio di mariologia, Torino 1995.

Congar Y. M. J., Wierze w Ducha Świętego, t. I, Duch Święty w „ekonomii”. Objawienie i doświadczenie Ducha, tłum. A. Paygert, wstęp S. C. Napiórkowski, Warszawa 1995.

De Fiores S., Immacolata, [w:] Nuova Dizzionario di Mariologia, ed. S. De Fiores, S. Meo, Roma 1985, s. 697-707.

De Fiores S., Maria partecipe della gloria di Cristo risorto. Apporti e prospettive, [w:] L'Assunzione di Maria Madre di Dio. Significato storico-salvifico a 50 anni dalla definizione dogmatica, ed. G. C. Moralejo, S. Cecchin, Città del Vaticano 2001, s. 668-698.

Dokumenty Soborów Powszechnych, red. A. Baron, H. Pietras, t. 1, 325-787, Kraków 2001 (Źródła Myśli Teologicznej, 24).

Enchiridion symbolorum definitionum et declarationum de rebus fidei et morum, Barcinione $1973^{36}$.

Evdokimov P., La donna e la salvezza del mondo, Milano 1980. 
Ewangelia wedtug św. Łukasza, tłum., wstęp, komentarz H. Langkammer, Radom 2005.

Forte B., Maria, la donna icona del Mistero. Saggio di mariologia simbolico-narrativa, Milano 1989.

Fusi A., Ha creduto meglio degli altri. Maria modello della Chiesa nell'insegnamento di Giovanni Paolo II, Milano 1999.

Grossi G., Maria custodiva e meditava la parola, Padova 2003.

Jan Paweł II, Encyklika Redemptoris Mater, [w:] Encykliki Ojca Świętego Jana Pawła II, Kraków 2003, s. 221-271.

Jan Paweł II, Discorso durante l'udienza generale (10 gennaio 1996), „L'Osservatore Romano" 1996, 11 gennaio, s. 1-2.

Giovanni Paolo II, Discorso dell'Angelus (29 maggio 1983), „Insegnamenti” VI, 1, 1390.

Kudasiewicz J., Matka Odkupiciela, Kielce 1996 (Maryja w Dziejach Zbawienia, 1).

Lambiasi F., Lo Spirito Santo: mistero e presenza. Per una sintesi di pneumatologia, Bologna 1987.

Laurentin R., Esprit Saint et theologie mariale, „Nouvelle Revue Théologique” 89 (1987), s. 24-37.

Laurentin R., I vangeli dell'infanzia di Cristo, Roma 1986.

Maggi A., Nostra Signora degli eretici. Maria e Nazaret, Assisi 1997.

Manelli S., Mariologia biblica, Frigento 2005.

Mary in the New Testament, ed. R. E. Brown J. A. Fitzmyer, K. P. Donfired, New York 1978.

Mary Coredemptrix, Mediatrix, Advocate. Theological foundations, t. I, Towards a papal definition?, ed. M. Miravalle, Santa Barbara CA 1995.

Mary Coredemptrix, Mediatrix, Advocate. Theological Foundations, t. II, Papal, pneumatological, ecumenical, ed. M. Miravalle, Santa Barbara CA 1996.

Mary Coredemptrix. Doctrinal Issues Today, ed. M. Miravalle, Goleta CA 2002.

Masciarelli M. G., Maria icona perfetta dell'umanità pervenuta per grazia al suo compimento, [w:] L'Assunzione di Maria Madre di Dio. Significato storico-salvifico a 50 anni dalla definizione dogmatica", ed. G. C. Moralejo, S. Cecchin, Città del Vaticano 2001, s. 376-431.

Masini M., Maria di Nazaret: storia, mito, simbolo, interpretazioni, Padova 2006 (I Volti di Maria di Nazaret, 2).

Menke K. H., Incarnato nel seno della Vergine Maria. Maria nella storia di Israele e nella Chiesa, Milano 2002.

Miravalle M., With Jesus. The story of Mary co-redemptrix, Goleta CA 2003.

Napiórkowski S. C., Trójca Święta i Maryja oraz teologowie Polscy, [w:] Trójca Święta a Maryja. Materiaty z sympozjum mariologicznego zorganizowanego przez 
Polskie Towarzystwo Mariologiczne. Częstochowa, 6-8 września 1999 roku, red. nauk. T. Siudy, K. Pek, Częstochowa 2000, s. 5-6.

Nossol A., Wprowadzenie, [w:] Wokót tajemnicy Ducha Świętego. Materiaty Seminarium Wykładowców Dogmatyki. Góra Świętej Anny 20-21.10.1998, red. P. Jaskóła, Opole 1998, s. 5-6 (Sympozja, 27).

Ozorowski E., Czy traktat o Trójcy Przenajświętszej może się obejść bez nauki o Maryi?, [w:] Trójca Święta a Maryja. Materiały z sympozjum mariologicznego zorganizowanego przez Polskie Towarzystwo Mariologiczne. Częstochowa, 6-8 września 1999 roku, red. nauk. T. Siudy, K. Pek, Częstochowa 1999, s. 7-18.

Perrella S. M., La Madre di Gesù nella coscienza ecclesiale contemporanea. Saggi di teologia, Città del Vaticano 2005.

Prete B., Nuovissimi studi sullopera di Luca. Contenuti e prospettive, Torino 2002.

Rahner K., L'Immacolata Concezione. Saggi di Cristologia e Mariologia, Roma 1965.

Rahner K., Maria, Madre del Signore, Fossano 1962.

Serra A., Aspetti mariologici di Lc 1,35, [w:] „Maria e lo Spirito Santo”. Atti del IV Simposio Mariologico Internazionale (Roma 1982), Roma-Bologna 1984, s. 133-200.

Serra A., Il Padre celeste e la Madre terrena. Convergenze nella storia della salvezza, [w:] Maria e il Dio dei nostri padri, Padre del Signore nostro Gesù Cristo. (XII Simposio Interna zionale Mario logico. Roma, ottobre 1999), ed. E. Toniolo, Roma 2001, s. 217-233.

Sobór Watykański II, Konstytucja dogmatyczna o Kościele Lumen gentium, [w:] Sobór Watykański II. Konstytucje, dekrety, deklaracje, Poznań 2002, s. 104-166.

Thurian M., Maryja Matka Pana, figura Kościoła, przeł. E. Ogiński, Warszawa 1990 (Theotokos. Seria Mariologiczna, 2).

Życiński W., Encyklika Redemptoris Mater, [w:] Zrozumieć, aby czcić. Encykliki Jana Pawta II, red. M. Cholewa i in., Kraków 2014, s. 91-105.

Życiński W., Mariologia, [w:] Dogmatyka w perspektywie Bożego Miłosierdzia, red. K. Góźdź, K. Guzowski, Lublin 2010, s. 135-145. 